\title{
Seals (Halichoerus grypus) of Cornwall Coasts.
}

\author{
By \\ G. A. Steven, B.Sc., F.R.S.E. \\ Assistant Naturalist at the Plymouth Laboratory.
}

(Report to the Ministry of Agriculture and Fisheries-30th September, 1935.)

With 6 Figures in the Text.

I. INTRODUCTORY.

IT has long been known that there is a considerable seal population on the North Cornwall coast. But precise information concerning the species present, the density of the population, and the positions of the rookeries has been almost entirely lacking. In order to obtain data on these points, a detailed survey of the North Cornwall coast was carried out during the fortnight August 7th-20th (1935) inclusive.

On this coast the seals live in caves. All the caves of any size or possible importance were visited and explored. With only a very few exceptions, direct landings from a boat could not be made in the caves. Because of the narrow and difficult openings of most of them and of the surf which was breaking in them even on what appeared to be "dead calm " days, it was usually unsafe for a dinghy to go right in and landing had to be made by swimming.

The method employed was to visit the various fishing ports and villages and hire a motor-boat and dinghy with and from which to explore the shores. The places at which boats were hired were St. Ives, Portreath, Newquay, Padstow, and Port Isaac. At all those places the advice and assistance of fishermen and others interested in the work were freely given and gratefully received. Without the friendly counsel and information which they were able to supply, the difficulties connected with the work would have been very greatly enhanced. At all times, such additional observations as were possible from the land were also made in order to supplement those carried out from the seaward side.

While engaged on this work I was accompanied by Midshipman G. P. Blake, R.N., of the Royal Naval College, Keyham, Devonport, who rendered invaluable assistance both ashore and afloat. Because of the danger involved, it was considered unwise for only one person at a time to enter the caves. Mr. Blake therefore accompanied me into every one of them : in fact, he was usually the first to set foot on their beaches and the last to leave. 
The precaution was taken always to work difficult caves on a falling tide. Usually, on each day, from the time that the first cave was entered until operations ceased, we had to work clad only in bathing dress. As a consequence of these lengthy periods spent in a damp or wet garment and of extensive exposure alternately to the heat of the sun outside and the damp, dismal chilliness of the cave interiors, both Blake and myself became afflicted with a disorder of the skin which can best be described as resembling miliaria or "prickly heat" and which caused us considerable discomfort.

The interiors of the caves were all so dark, many of them in their inner recesses being in total darkness, that it was necessary to carry lamps in order to explore them. Two Lucas "Ever-ready" searchlight torches, No. 2223, were used. Ordinary pocket flash-lamps were also carried as additional (emergency) units. One of the chief difficulties to be overcome when, as was usual, direct landing could not be made, was the safe transit of the torches from the dinghy to the cave beach. It was found necessary to seal with electrician's insulating tape all apertures in the lamps through which water could enter them. The lamps were then placed in a tin box-a large biscuit tin-which was also sealed with rubber tape. By means of a line attached to it this box, with the torches safe inside, could sometimes be towed ashore behind a swimmer. When conditions made this method impracticable or impossible — e.g. a breaking surf which would buffet the box about too much-one of us entered the cave with a rope by means of which he later hauled ashore the box. In some instances, numerous wholly or partially submerged rocks were serious obstacles in the cave entrance. When these were encountered one of us landed on the nearest rock and the box was thrown to him. The other then swam to the next foothold farther in and in turn received the box, this process being repeated as necessary until the cave beach was reached. Not infrequently a combination of methods had to be used.

\section{The Caves.}

Although seals are to be observed from time to time all along the North Cornwall coast, caves which they can and do inhabit are not uniformly distributed along that shore. Where suitable caves do exist, therefore, the seals congregate into colonies (=rookeries). From thence they disperse in all directions to forage for food, residing for the time being in temporary or even semi-permanent resting-places-termed "seal lodges" in this report (defined below).

So far as seals are concerned, there are three types of cave in Cornwall. These are : (1) Caves in which seals can and do reside permanently and in which they can successfully bring forth their young. Such caves have 
beaches and/or rock ledges which lie or extend sufficiently far above highwater mark to ensure their not becoming submerged in any state of the tide or weather. For purposes of reference these caves may be termed Seal Caves. (2) Caves which the seals habitually visit, often in considerable numbers, but which cannot form for them a permanent home, and in which successful breeding must be difficult or impossible, as no beaches or adequate ledges remain uncovered during high tide. Such caves may be called Seal Lodges. (3) Caves in which seals are seldom or never found. Those which dry out completely to or beyond their mouths at low tidé, or, for any other reason, are periodically or permanently easily accessible from either land or sea are, as a rule, avoided by the seals. Such caves are referred to as Unused Caves.

\section{The Survey.}

Seals are common on the North Cornwall coast, but they are seldom seen along that county's southern shore. There is, however, at least one seal lodge on the south coast, situated at Prussia Cove (O.S. 146).* On the eastern side of this small cove, at about half-tide level, a small hole in the shelving rocks leads underground into a subterranean cavern of considerable size, the floor of which slopes quickly down under water. From this entrance the cave extends eastwards for some fifty or sixty yards $\dagger$ where another entrance connects directly with the sea through a deep, water-filled gully, too narrow to admit even a very small punt. Even at low tide the cave remained largely filled with water, so it had to be explored by swimming (Fig. 1).

From the main chamber a large recess branches off northwards (i.e. landwards) and ends in a gravelly beach on which, after the rest of the cave had been fully explored, a landing was made. Little light enters the cave, and this beach is in total darkness. As far as could be ascertained, it must be completely submerged at high tide. There are no large ledges in this cave, so it seems unlikely that it can be other than a more or less permanent seal lodge. Because of its relatively small size it cannot support a large population. Only one seal-a large grey-was found actually in the cave and none were observed outside or anywhere in the vicinity. Local fishermen state, however, that in their opinion not more than from six to ten seals lodge in the cave. This seems a reasonable figure.

Apart from this small colony at Prussia Cove, seals are seldom found in Mount's Bay. But immediately Land's End is reached seals become common. They are frequently encountered in considerable numbers

* In this report the letters "O.S." followed by a number refer to the Ordnance Survey one-inch map of that number.

$\dagger$ Estimated distance. 
among the Longships Rocks; and from thence all along the rocky shore northward to St. Ives Head some seals are generally to be found. Within this area, however, their most favoured haunts are the Carrack Rocks (about $3 \frac{1}{2}$ miles west of St. Ives; O.S. 146) and their vicinity. But although this part of the shore is much frequented by seals, presumably for feeding purposes, caves are few, insignificant, and mainly unused.

Beyond St. Ives Bay, the shores of which are mostly sand, the next rocks are found at Godrevy Point (O.S. 146). The shores of this headland and beyond to Navax Point, Hell's Mouth, Deadman's Cove, and eastwards to Portreath, are other favourite haunts of the seals. But although

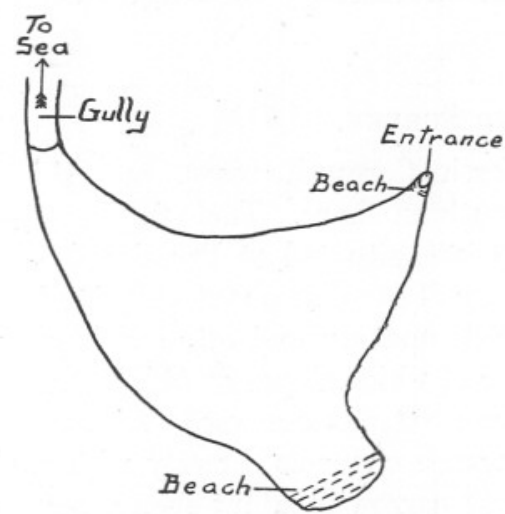

Fig. 1.-Cave at Prussia Cove.

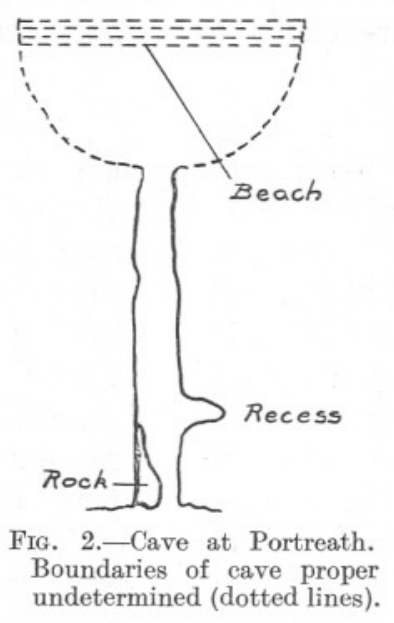

there are numerous caves, large and small, at Hell's Mouth-all of which were entered and fully explored*-none of them can serve for permanent residential and breeding purposes. Several are well fitted to act as seal lodges and apparently are much used as such, though no seals were present in any of them at the time of our visit.

The first seal cave proper is situated in the tip of the headland-known as Tregea Hill - on the south side of Portreath Bay, about one half-mile from Portreath harbour (O.S. 143 and 146). This cave extends in through the rock in the form of a long straight tunnel which opens out into a large cavern with an extensive gravel beach. The mouth of this cave is largely blocked by a big rock which leaves a very narrow channel through which a small dinghy can only just be coaxed to pass, and that only in the most favourable weather conditions. When it is too rough to take a dinghy through —as on all our three visits-landing may often still be made on the obstructing rock. From this rock a small part of the cave

* These caves received special attention because, before we explored them, we believed them to be important breeding places. 
beach is discernible in the distance, but in order to land thereon it is necessary to swim through the intervening deep water-about 70 or 80 yards estimated distance (Fig. 2).

When, after a previous unsuccessful attempt, this cave was first entered (by landing on the rock) two seals could be dimly discerned lying on the beach inside. Twenty-four seals were later driven out of this cave and counted as they passed through the narrow channel at the entrance. In addition, eleven others had previously been seen outside, making a total of thirty-five seals counted in or near this cave-all Grey Seals, Halichoerus grypus. On the same day that this cave was visited one other seal was passed at Godrevy Point and from sixteen to twenty seals were reported to me as having been seen in the vicinity of the Carrack Rocks. All these must have their main base at Portreath although, as explained above, probably occupying suitable lodges elsewhere (e.g. the Hell's Mouth caves) from time to time. As far as can be judged, the Portreath cave is capable of housing a colony of anything up to 150 seals. Having regard to the fact that up to about 100 have actually been seen at one time in its immediate vicinity (vide letter in Western Morning News and Mercury, 7th December, 1932) it seems fairly certain that the strength of this colony exceeds 100 seals with a maximum of not more than 150 animals.

About midway between Portreath and Porthtowan are two other seal caves which, however, at the time of our visit, were empty. An explanation of this was supplied by Mr. Landry, of Factory Farm, Porthtowan, whose land borders that part of the shore in which these caves are situated. Both caves can be reached without very much difficulty from the land at low tide.* During the summer months these caves are visited not infrequently by holiday-makers and the seals depart. But in late autumn, when they are no longer disturbed, some seals return to the caves to breed. At the present time they must be attached to neighbouring colonies.

From Porthtowan northwards to Kelsey Head, which lies about three miles south-west of Newquay, there are but few caves, mostly unused. In Kelsey Head, however, immediately inside the Chick Rock on its southern side, is a large seal cave (O.S. 143). Its mouth is narrow and difficult and an entrance can be effected only by landing on the steep rock on its northern side and climbing to the top of it-about 20 feet up. It is then possible to descend the inner side of this rock and enter the cave (Fig. 3). It is filled for most of its length by huge boulders over and amongst which it is exceedingly difficult to make one's way. At its inner end the cave expands slightly into a somewhat oval-shaped chamber in the bottom of which is a large pool. There is in this cave a good deal of accommodation at all states of the tide, the tips of many of the boulders

\footnotetext{
* One can also be entered through a disused mine shaft.
} 
rising above high-water mark and the sides of the cave being furnished with numerous ledges. Although no seals were found actually in this cave, at least thirteen were counted swimming about outside on the day that it was entered.

A short distance to the southward of the above seal cave is another much used by seals. Across its entrance is a large rock which was just awash at the time of our visit. Some distance inside this rock there is an excellent gravel beach ; the whole floor of the cave, in fact, consists of fine gravel in which several newly made seal tracks were found. The seals had gone out before we were able to land. This cave, however, is

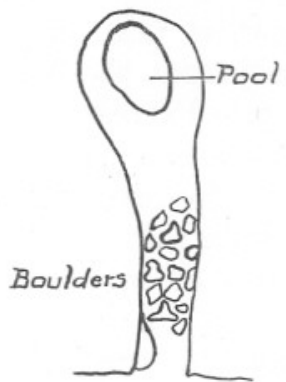

Fig. 3.-Cave at Kelsey Head.

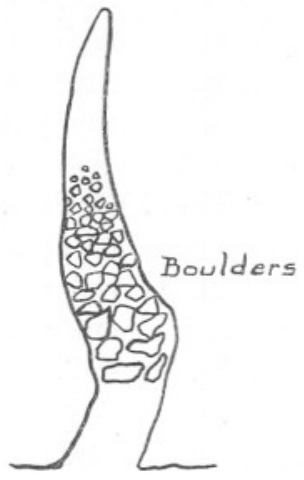

Fig. 4.-Cave at Trevose Head.

simply a lodge ; it possesses no high ledges and its floor must all be covered at high tide.

Other caves in this vicinity are unsuitable for general use by seals, though some may serve occasionally as unimportant lodges.

At Kelsey Head, then, we counted 13 seals-all $H$. grypus. Fishermen whom we consulted estimated the total population of this locality to be from 20 to 25 seals. It seems safe, therefore, to place the strength of the Kelsey Head colony at from 20 to 30 individuals.

Between Kelsey Head and Newquay there is another seal cave in the rocks at the tip of Pentire Point East. Like its neighbour at Kelsey Head, this cave also is filled with gigantic boulders the tops of many of which must remain permanently uncovered. There are also some ledges at the sides. This, however, is a relatively small cave and could accommodate only a small colony of seals. On the two occasions on which this cave was visited a few seals - all H. grypus - were seen. Three were counted on the first occasion when it was too rough to land and five on the second occasion when the cave was explored. No seals were found actually inside. From these numbers and from the nature of the cave I estimate the strength of this colony to be not less than ten and not more than twenty 
individuals. This agrees well with the estimate of local fishermen who, ignorant of the total at which I had arrived, placed the strength of this colony at "about a dozen seals."

Continuing north from Pentire Point East, the next seal cave (Fig. 4) is found at Trevose Head, opening from a small cove south of the lighthouse and directly under it (O.S. 136). Beyond the deep water which extends some distance into this cave there are exceedingly large boulders. Inside these boulders are smaller ones, while still farther in the cave narrows, all boulders are left behind, and an elongated pool several feet deep covers the cave floor. In this cave there are large crags and ledges at all heights, providing good accommodation for seals at all times. While making our way out of this cave, although no seals had previously been seen inside, we were surprised to find two large grey seals behind us, clambering over the boulders amongst which they must have been lying, hidden from the light of our torches. The rapid and successful progress of the seals over and amongst the very largest of those boulders which almost barred our way, was noteworthy. In addition to the two seals which followed us out of the cave, at least six others were counted swimming about outside. The number of seals seen at Trevose and the size and nature of the cave agree closely with what we found at Kelsey Head. These two colonies may, therefore, safely be considered to be of approximately the same size -twenty to thirty seals. Fishermen's independent estimates for the Trevose locality varied from twelve to twenty-five seals.

There is another large seal-frequented cave at Gunver Head (Fig. 5), about three miles east of Trevose. Deep water extends some way in and landing had to be made among some fairly large rocks well inside the cave entrance. These rocks give place successively to pebbles, gravel, and finally to fine sand. At its inner end the cave expands into a chamber of considerable size with a sandy floor. There are two entrances to this chamber, one of which was so small that one could crawl through it only with difficulty. The second entrance-which we did not notice at first or we should not have crawled through the first one !-is much larger. This is a very long cave and we found it difficult to be certain whether all the beach at the far end would be covered with water at high tide. Our general impression was that it would be. If this be so, then this cave can be only a seal lodge, as it possesses no ledges of any magnitude. On the other hand, one or more seals were seen near it on each of the three occasions on which it was visited. On our last visit, when the cave was explored, four seals (the largest number) were counted outside, though none were found inside. It is just possible, therefore, that this is a true seal cave and that it may accommodate a residential colony of not more than from ten to fifteen seals.

From Gunver Head to Pentargon there are, here and there, several 
unused caves and one or two which may perhaps be used occasionally as lodges.

At Pentargon, near Boscastle (O.S. 136), there is what appears to be a seal cave. On our visit, three seals were seen in its vicinity but none inside the cave itself. This colony, therefore, if it exist at all, can scarcely exceed ten individuals.

Just beyond Pentargon Cove are the Beeny High Cliffs in which there are numerous small unused caves. But just inside the rocks called Beeny Sisters at the place known as Fire Beacon Point, there are three exceedingly large residental caves (Fig. 6). Although it was found impossible fully to explore these caves, they appeared to be the largest of any we

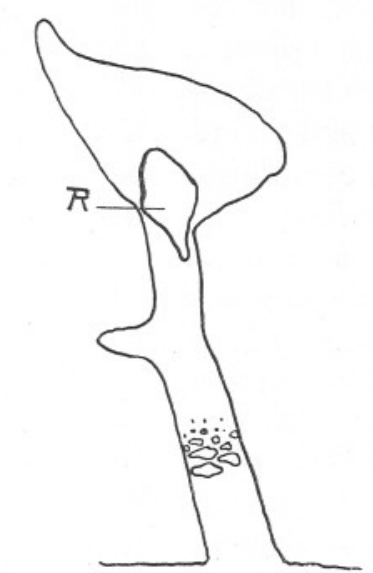

Fig. 5.-Cave at Gunver Head. $\mathrm{R}=$ large column of rock.

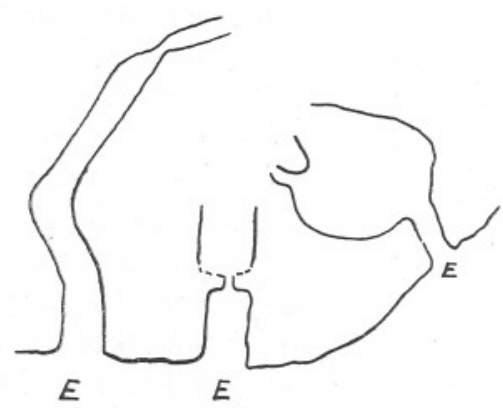

Fig. 6.-Caves at Fire Beacon Point. $\mathrm{E}=$ entrance to caves.

had seen. Their openings are all close together and not unduly large. The northernmost cave-i.e. the nearest one to the Beeny Sisters-consists of a long and narrow, but high, corridor extending inwards for a long way and curving towards the right. Its width, which remains fairly uniform for as far in as we were able to penetrate-an estimated distance of from 80 to 120 yards - was just sufficient to allow of the free passage of a dinghy. Eventually, however, the passage narrowed and we could proceed no farther. As far as we went in, and beyond for as far as we could seethis distance being limited by the curve of the cave-there was deep water. By the light of our torches we could see numerous seals swimming about in the water inside of us, while others could be seen and heard plunging from high ledges. It was impossible further to explore and examine this cave. To do so it would have been necessary to swim farther in. This was considered too risky as, once beyond reach of light from the dinghy, the swimmer would have been in total darkness and might have found it 
difficult or even impossible to find his way back. Nevertheless, we were able to satisfy ourselves that this great cave is well provided with ledges at all heights and houses many seals.

A little farther along, in the direction away from Beeny Sisters, there is another cave which was also entered for a short distance. Further progress was completely barred by a sudden constriction of the cave to a narrow slit, too narrow even to swim through in the conditions prevailing at the times of our visits. This narrow part continues for only a short way and through it the cave could be seen to open out again beyond. Still farther along, but around a small bend in the cliff, is a third large cave which runs into the rocks roughly at right angles to the other two. The entrance is narrow but quickly opens out into a large, pitch-dark subterranean cavern in which there is room to row about quite freely. From this cavern two extensions continue inwards, but because of the low roof of the one and the narrowness of the other it was impossible to enter them. For reasons similar to those mentioned above, it was also considered undesirable to swim into them in the hope of finding a beach. They appeared, however, to continue towards - and almost certainly join up with - the two other caves already described. No live seals were seen in this cave but some could be heard in the distance, the sounds coming from somewhere near where we judged cave number one to be. A dead seal, a small grey, was picked up, however, and taken on board for examination.

Along the base of Beeny High Cliffs, inside of and extending northwards from the Beeny Sisters, is a fairly extensive beach consisting largely of massive boulders. A landing was made on this beach and all the caves in the cliffs behind fully explored. None of them are suitable for either seal caves or seal lodges.

Beyond this beach, still proceeding northwards, is a small bay having on its northern side, and close to the shore, an islet called Beeny Island or Gull Rock. Hard by this island, to northward, in the small headland called Buckator (O.S. 136), are three* large caves which previously I had thought to be important seal caves. All three were entered and fully explored. They proved to be all seal lodges only. The floors of all of them must be fully covered at high tide, and they are all devoid of ledge accommodation.

It can now be stated definitely, therefore, that the seal colony, well known to fishermen to be situated somewhere near Beeny Sisters-on which seals are often seen basking in the sunshine-is situated in the caves at Fire Beacon Point and not, as many of them had supposed, in the caves hard by Beeny Island. The latter caves are, however, evidently

* What, on a previous visit, I took to be the submerged opening of a fourth cave was. found to be only a large recess in the cliff base. 
much used as lodges. It is possible at low tide to discern their beaches from outside. Seals are therefore much more likely to be observed in them than in the impenetrable caverns at Fire Beacon Point, which are their true residences. It is thus easy to understand how the Buckator caves came to be considered more important than they really are.

As explained above, it was found impossible fully to explore the caves at Fire Beacon Point, or even to count the seals which were seen in them. As far as could be made out, at least a dozen different individuals came within range of our torches. How many more were in the caves at that time is not known. When we emerged from the caves, however, a large number of seals had appeared outside. Although an exact count was difficult to obtain, the number arrived at was twenty-six individuals. That is to say, approximately thirty-eight live seals were counted in addition to one dead one. From these numbers and the nature of the caves - as far as this could be ascertained-I arrived at the conclusion that the seal colony at Fire Beacon Point is of approximately the same numerical strength as that at Portreath-i.e. one hundred to one hundred and fifty seals. Three fishermen, with long experience of this part of the coast, and all unaware of the figure at which I had arrived, separately and independently gave "about 150 seals" as their estimate of the number having their headquarters in that area. It would appear, therefore, that this figure is reasonably reliable.

There are no seal caves farther north than Fire Beacon Point.

\section{Total Number of Seals.}

North Coast. It can now be stated that the seal colonies on the North Cornwall Coast are situated at Portreath (Porthtowan), Kelsey Head, Pentire Point, Trevose Head, Gunver Head (?), Pentargon (?), and Fire Beacon Point, in Beeny High Cliffs. As far as can be ascertained the numerical strengths of these several colonies are as follows :-

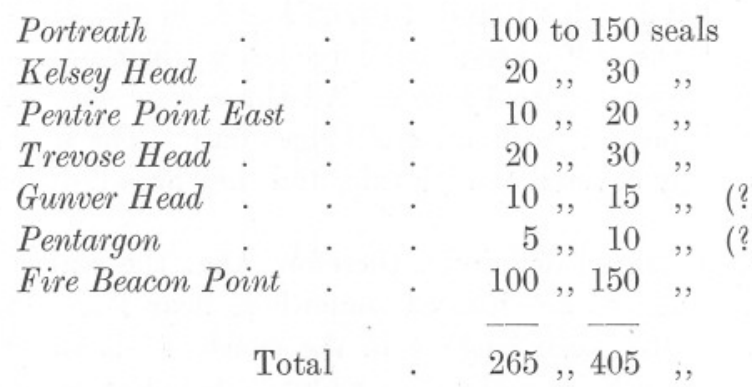

Allowing a fairly generous margin for errors and omissions it can safely be stated that the total seal population of the North Cornwall coast is not less than about 300 and probably not more than 500 individuals. Although 
difficult to measure accurately, North Cornwall may be considered to have a total coastline - including bays, coves, inlets, etc., but excluding estuaries -of approximately 100 miles. The density of the seal population on this coast, then, amounts on an average to from 3 to 5 seals per mile for every mile of shoreline. Although these numbers fall far short of an estimate of $2000^{*}$ seals put forward by the Fishery Officer to the Cornwall Sea Fisheries Committee, they are surprisingly large. They denote a seal population from three to five times as dense as that on the South Wales coast, for example, where Lockley estimates the number to average only about one seal to every mile of shoreline.*

If, to the present population of, say, 500 seals, be added the 177 seals which were shot last year, $\uparrow$ the total seal population at the beginning of 1934 must have been roughly 700 animals or approximately 7 individuals to every mile of coast. There can be no doubt, therefore, that several years of organised shooting with an annual "bag " of this magnitude would quickly reduce the North Cornwall population to an insignificant number.

It has not been possible in this survey to collect any data which will indicate whether-apart from interference by man-the seal population of Cornwall is increasing, decreasing, or static. Nor is any light thrown on the highly important possibility of an influx of seals from other localities at certain times - e.g. during the herring-fishing season.

South Coast. There are but few seals on the south coast. Only the small colony at Prussia Cove was visited. There may possibly be one or more additional small colonies in the vicinity of Lizard Point, but this locality was not investigated. No estimate of the number of seals on Cornwall's southern shore can therefore be given, but it certainly is very small.

\section{Species of SEal.}

At all points where residential caves were found, and elsewhere along the shore where seals were sighted, they were viewed from close range with binoculars. Every seal seen was, without exception, a Grey SealHalichoerus grypus. Not a single Brown Seal, Phoca vitulina, was encountered. There can be little doubt, therefore, that the Brown Seal, if present at all, is very rare around those shores. It would seem that recent references to this species of seal in Cornwall must, almost certainly, have been duẻ to faulty identification.

\footnotetext{
* Unpublished data. See also addendum on p. 506.

$\dagger$ Cornwall Sea Fisheries Committee. Fishery Officer's Report, 1934.

+ But becoming proportionately smaller, of course, as seals became fewer.
} 


\section{BReEding.}

Seals of all sizes and (presumably) of all ages from about one year old upwards were seen. But no seal pups were observed. The breeding season evidently had not yet begun.

Wednesday, $7 / 8 / 35$.

VII. LoG.

Proceeded to Boscastle. Failed to obtain suitable boat for cave work. Visited Pentargon Cove by land. One seal-large grey-observed. Proceeded to Port Isaac and arranged with Mr. S. Thomas for hire of motor-boat and dinghy on the following day if weather suitable.

Thursday, 8/8/35.

At Port Isaac.

Out in Boy Jack. Too rough to land anywhere. Two seals-grey-seen at Pentargon and four near Beeny Sisters. Proceeded to Padstow and arranged with Mr. Orchard for hire of boat Tamar and punt on the following day.

Friday, 9/8/35.

At Padstow.

Out in Tamar. Too rough to land anywhere. One seal-grey-seen at Gunver Head and one at Trevose Head. None elsewhere. Proceeded to Newquay and arranged with Mr. J. Harris for hire of boat Fairy and punt on the following day if not too rough to go out.

Saturday, 10/8/35.

At Newquay.

Out in Fairy. Could not land anywhere. Three grey seals seen at Pentire Point East and ten at Kelsey Head. None elsewhere.

Proceeded to Portreath and arranged with Mr. E. H. Hicks for hire of his punt on the following day if fine.

Sunday, 11/8/35.

At Portreath.

Out in punt to Ralph's Cupboard and vicinity but too rough to land. Three seals - grey - seen at tip of headland called Tregea Hill (O.S. 143 and 146). Walked along cliffs to Ralph's Cupboard where seals are reported often to lie on a small beach visible from the land but accessible only from the sea. One seal seen. Seven seals, all grey, seen near cave in tip of Tregea Hill headland.

Monday, 12/8/35.

At Portreath.

Too rough to go out. With assistance of Messrs. G. Davy and E. H. Hicks attempted to dig up bones of seals shot last year and buried in the sand of Portreath Beach. Skulls wanted for examination. Failed to find the skeletons. Public Health officer from Redruth arrived to hold up operations-which, 
however, had already ceased owing to failure to locate exact positions of burials.

Weather became hopelessly rough in afternoon so returned to Plymouth.

Tuesday, 13/8/35.

At Plymouth.

Wednesday, 14/8/35.

At Plymouth.

Telephoned to Port Isaac to inquire concerning weather conditions on North Coast. Received report that sea was calming down. Proceeded to St. Ives, and arranged with Mr. R. Ninnes for hire of boat $A d a$ and punt on the following day, if fine.

Thursday, 15/8/35.

At St. Ives.

Out in $A d a$. Shores explored, caves entered, and seal colony at Portreath located; 36 seals seen-all grey. On coming ashore proceeded to Porthtowan. Interview Mr. Landry, of Factory Farm, concerning the caves under his land (vide p. 497 of this report).

Proceeded to Port Isaac.

Friday, 16/8/35.

At Port Isaac.

Too rough to land anywhere so did not go out. Telephoned to Padstow. Coastguard thought landing possible at Trevose and vicinity.

Proceeded to Padstow. Out with Mr. Orchard. Couldn't land anywhere. One seal-grey-seen at Gunver Head and one at Trevose. None elsewhere.

On return, proceeded to Prussia Cove as sea smooth on south coast.

Saturday, 17/8/35.

At Prussia Cove.

Explored cave. One seal-grey-seen at eastern entrance. Telephoned to Port Isaac. Received report of improving conditions there. Explored shore - from landward - from Cape Cornwall to Mussel Point (O.S. 146). One seal seen at Gurnard's Head-very large.

In evening, carried on to Port Isaac.

Sunday, 18/8/35.

At Port Isaac.

Out with Mr. J. Lark in boat Shamrock. Shores explored; caves entered; and seal colony located at Fire Beacon Point (vide p. 500 of this report).

In evening, proceeded to Padstow.

Monday, 19/8/35.

At Padstow.

Out with Mr. W. England in boat Celia. Shores explored, caves entered, and seal colonies located at Gunver Head and Trevose (vide p. 499 of this report). 
Tuesday, 20/8/35.

Proceeded to Portreath in early morning in order to re-enter seal cave there at high water in order to verify previous conclusion that large beach left uncovered. Conclusion found correct.

Returned Newquay.

Out with Mr. J. Arthur in boat Charlie. Shores explored, caves entered, and seal colonies at Kelsey Head and Pentire Point East located (vide p. 497 of this report).

Returned Plymouth at night.

\section{BIBLIOGRAPHY.}

Havinga, B. Der Seehund in den Hollandischen Gewassern. Tijdskrift der Ned. Dierkundige Vereenigung, 3de Serie, Deel III, Aflevering 2 en 3. 1933.

HлоRт, Јон. and KnIPowitsch, N. Bericht über die Lebensverhaeltnisse und den Fang der nordischen Seehunde. Conseil Internat. pour l'Exploration de la Mer. Rapp. et Procès-verb., VIII, 1907.

Hudson, W. H. The Land's End, 1908.

Mrllais, J. G. The Mammals of Great Britain and Ireland, Vol. I, 1904.

Southweld, T. The Seals and Whales of the British Seas, 1881.

Steven, G. A. A Short Investigation into the Habits, Abundance, and Species of Seals on the North Cornwall Coast. Jour. Mar. Biol. Assoc., N.S., Vol. XIX, No. 2, 1934.

Tregarthen, J. C. Wild Life at the Land's End. 1904.

\section{ADDENDUM.}

Since this paper went to press I have been informed by Lockley (see p. 503) that the seal concentrations on the islands off-shore are not included in his estimate of one seal to every mile of shoreline on the South Wales coast. If these island populations be taken into account Lockley's figure for South Wales is approximately doubled. On the Pembrokeshire coast, where the seals are most numerous, Lockley finds the density of population to be about the same as that of North Cornwall. 